\title{
FAKTOR-FAKTOR YANG BERHUBUNGAN DENGAN TINGKAT KECEMASAN ORANG TUA TERHADAP HOSPITALISASI ANAK USIA PRASEKOLAH
}

\author{
Ani Rahmadhani Kaban*, Veronica Anggreni Damanik, Chintya Siahaan \\ Fakultas Farmasi dan Kesehatan, Institut Kesehatan Helvetia, Jln Kapten Sumarsono No. 107, Helvetia, \\ Medan, Sumatera Utara 20124, Indonesia \\ *anikaban92@gmail.com (+6282163372514)
}

\begin{abstract}
ABSTRAK
Anak yang sedang sakit cenderung orang tua dan keluar tidak optimal dalam merawat anak dirumah. Keadaan yang seperti itu memaksakan anak harus untuk dirawat di fasilitas kesehatan. Hospitalisasi anak usia prasekolah merupakan suatu proses darurat, untuk dirawat di fasilitas kesehatan. Penelitian ini bertujuan untuk mengetahui faktor yang terkait dengan tingkat kecemasan orang tua terhadap hospitalisasi anak usia prasekolah. Desain dari penelitian ini adalah Survey Analitik dengan pendekatan Cross Sectional. Populasi dalam penelitian ini adalah orang tua yang memiliki anak usia prasekolah yang berjumlah 163 orang. Teknik sampel yang digunakan dengan cara Purposive Sampling, dengan jumlah sampel berjumlah 62 responden. Hasil analisa data dengan menggunakan.Uji Chi-Square test yang memperlihatkan bahwa nilai signifikan probabilitas hospitalisasi adalah $\alpha=0,05$. Maka diperoleh $0,022<0,05$ yang artinya ada hubungan lama rawat inap dengan tingkat kecemasan orang tua, $0,043<0,05$ yang berati ada hubungan tingkat pengetahuan dengan tingkat kecemasan orang tua, dan 0,024 $<0,05$ yang artinya ada hubungan perilaku Caring perawat dengan tingkat kecemasan orang tua. Kesimpulan yang didapatkan pada penelitian ini ada hubungan rawat inap, tingkat pengetahuan, perilaku Caring perawat dengan tingkat kecemasan orang tua.
\end{abstract}

Kata kunci: hospitalisasi; perilaku caring perawat; rawat inap; tingkat pengetahuan; tingkat kecemasan

\section{ASSOCIATED FAKTORS PARENTS ANXIETY WITH HOSPITALIZATION PRE SCHOOL AGE CHILDREN}

\begin{abstract}
Children who are sick tend to be parents and are not optimal in caring for children at home. Such circumstances force the child to be treated in a health facility. Hospitalization of preschool age children is an emergency process, to be treated in a health facility. This study aims to determine the factors associated with the level of parental anxiety about hospitalization of preschool-aged children. The design of this research is an analytical survey with a cross sectional approach. The population in this study were parents who had 163 children of preschool age. The sampling technique used was purposive sampling, with a total sample of 62 respondents. The results of data analysis using the Chi-Square test which shows that the significant value of the probability of hospitalization is $=0.05$. Then obtained $0.022<0.05$, which means that there is a relationship between length of stay and parental anxiety level, 0.043 $<0.05$ which means there is a relationship between knowledge level and parental anxiety level, and $0.024<0.05$, which means there is a relationship between nurses' caring behavior. with parental anxiety level. The conclusion obtained in this study is that there is a relationship between hospitalization, level of knowledge, caring behavior of nurses and parents' level of anxiety.
\end{abstract}


Keywords: anxiety level; caring behavior nurse; hospitalization; inpatient; knowledge level

\section{PENDAHULUAN}

Anak merupakan bagian dari keluarga dan masyarakat dan merupakan pemberian Tuhan yang memiliki keistimewaan dan keindahan namun anak yang sakit dapat menimbulkan suatu stress (Kaluas, Ismanto \& Kundre, 2015). Anak prasekolah dimulai pada usia 3-5 tahun. Usia kanak-kanak anak dapat melakukan seperti gerakan, mengejar, melempar, menari dan berhitung Pada usia segini biasanya anak mampu melakukan berbagai gerakan seperti berlari, melempar, berhitung. Di Indonesia, jumlah anak usia prasekolah (3-5 Tahun) berdasarkan data Kementrian Kesehatan Republik Indonesia tahun 2016 jumlah anak usia pra sekolah 9.603.173 jiwa (Hulinggi, Masi \& Ismanto, 2018).

Berdasarkan data Profil Kesehatan Indonesia tahun 2018 persentase anak sakit atau angka kesakitan anak adalah 15,86 persen. Angka kesakitan anak di perkotaan sebesar 16,66 persen, relatif lebih tinggi dibandingkan dengan di perdesaan sebesar 15,01 persen. Tidak ada perbedaan yang signifikan dalam persentase anak wanita dan priayang sakit (Kemenkes RI, 2018). Anak yang sakit, orang tua tidak mampu memrawat anak dengan rumah. Keadaan yang seperti itu memaksakan anak dirawat di fasilitas kesehatan. Pada saat di fasiilitas kesehatan akan dalam keadaan hopitalisasi. (Windiarto \& Yanto, 2018).

Hospitalisasi adalah keadaan dimana seseorang akan dirawat oleh tenaga kesehatan dengan maksimal. Pada saat rawat inap di fasilitas kesehatan anak dan orang tua akan merasakan pengalaman traumatik dan penuh dengan stress. Kekhawatiran yang timbul antara lain kemarahan, keedihan, ketakutan dan rasa tidak berdaya. (Wulandari \& Erawati, 2016). Prevalensi hospitalisasi pada anak usia pra sekolah menurut data World Health Organisation (WHO) pada tahun 2015 ialah sebanyak $45 \%$ dari total jumlah perawatan anak usia pra sekolah yang di hospitalisasi di fasiltas kesehatan (WHO, 2015).

Hospitalisasi tersebut dapat menimbulkan kecemasan adapun yang menimbulkan kecemasan diperoleh dari beberapa faktor, baik dari tenaga kesehatan (perawat, dokter, dan tenaga medis), lingkungan baru, maupun keluarga yang mendampinginya (Sarfika, Yanti \& Winda, 2015). Kekhawatiranialah dimana perasaaan seseorang yang tidak memberikan kenyamanan yang ditandai dengan gejala fisiologis. Pada gangguan kekhawatiran terdapat rasa ketakutan yang berlebih yang menyebabkan ketidaknyamanan. (Anggika \& Wahyudi, 2016).

Pada usia prasekolah kegiatan anak yang padat akan menimbulkan keletihan yang mana anak menjadi kelelahan dan dapat jatuh sakit karena imun tubuh yang tidak bai sehingga anak harus menjalani hospitalisasi (Alini, 2017). Orang tua sangat diperlukan untuk mendampingi anak selama mendapat perawatan dirumah sakit. Peran orang tua dalam mengurangi rasa kekhawatiran akibat rawatan inap dengan memberikan kedekatan anak dan orang tua tinggal 24 jam mempertahankan kontak diantara keduanya, mempersiapkan psikologis anak untuk melakukan tindakan perawatan serta pemberian kedekatan fisik anak, jika anak dirawat dalam 
jangka waktu yang lama, maka orang tua akan membantu untuk membawakan mainan baru, memenuhi kebutuhan anak selama dirawat, membacakan buku-buku tentang rawat inap atau kunjungan dokter dengan anak (Rismalinda, 2017).

Penelitian Winarsih (2014) mengatakan bahwa sebagian besar anak yang tidak pernah dirawat dengan dampak hospitalisasi positif sebesar $55 \%$ dan sedangkan pendampingan orang tua dengan dampak hospitalisasi didapatkan bahwa $60 \%$ anak yang didampingi orang tua mempunyai dampak hospitalisasi yang positif terutama rasa kecemasan saat anak dihospitalisasi.

Dari hasil wawancara yang dilakukan pada pihak Rumah Sakit Mitra Medika Medan terdapat jumlah Hospitalisai anak usia prasekolah sebanyak 163 orang anak pada bulan Agustus sampai oktober tahun 2019 dengan pendampingan penuh orang tua. Berdasarkan masalah diatas maka dengan itu peneliti tertarik untuk meneliti Faktor-Faktor yang Berhubungan Tingkat Kecemasan Orang Tua Terhadap Hospitalisasi Anak Usia Prasekolah Di Rumah Sakit Mitra Medika Medan.

\section{METODE}

Penelitian adalah penelitian dengan survey analitik, yang mencoba untuk melihat secara dalam bagaimana dan mengapa fenomena itu terjadi. Kemudian melakukan analisis dinamika korelasi antara fenomena, baik antara faktor resiko dan faktor efek. Pendekatan yang digunakan adalah cross sectional untuk mengetahui faktor-faktor yang berhubungan dengan tingkat kecemasan orang tua terhadap hospitalisasi anak usia prasekolah di Rumah Sakit Mitra Medika Medan.
Penelitian ini dilakukan di Rumah Sakit Mitra Medika Medan. Populasi pada penelitian ini adalah 163 orang tua yang mempunyai anak usia prasekolah (3-5 tahun) yang dirawat di Rumah Sakit Mitra Medika Medan. Sampel dalam penenlitian ini sebanyak 62 orang dengan menggunakan metode purposive sampling. Analisa data menggunakan analisa univariat yang mendeskripsikan karakteristik keseluruhan responden, sampel, distribusi dan frekuensi variabel, analisis bivariat untuk melihat hubungan variabel dengan menggunakan uji Chi-Square.

\section{HASIL}

Tabel 1 Karakteristik responden didapatkan data pada karateristik usia orang tua dengan anak yang dihospitalisasi paling banyak di rentang usia 26-35 tahun (Dewasa Awal) sebanyak 52 responden (83,9\%). berjenis kelamin perempuan sebanyak 48 responden $(79,0 \%)$ pendidikan SMA sebanyak 38 responden (61,3\%), pekerjaan orang tua paling banyak IRT sebanyak 36 responden $(58,1 \%)$. Berdasarkan hubungan orang tua yang menemani anak pada dihospitalisasi dikatergori Ibu sebanyak 53 responden $(85,5 \%)$.

Tabel 2 Analisa Univariat didapatkan data pada kategori rawat inap anak pra sekolah yang di hospitalisasi sebanyak 42 responden $(67,7 \%)$ dari lama rawatan lebih dari 3 hari. Pada data tingkat pengetahuan orang tua pada anak pra sekolah yang di hospitalisasi dikategorikan kurang sebanyak 28 responden $(54,2 \%)$. Pada data perilaku caring perawat pada anak pra sekolah yang di hospitalisasi dimasukkan dalam kategori kurang sebanyak 34 responden $(54,8 \%)$. Pada data tingkat kecemasan orang tua pada anak pra sekolah yang di 
hospitalisasi dimasukkan dalam katerori berat sebanyak 32 responden (32\%).

Tabel 1.

Karakteristik Responden $(\mathrm{n}=62)$

\begin{tabular}{lcc}
\hline \multicolumn{1}{c}{ Karakteristik } & $\mathrm{f}$ & $\%$ \\
\hline Usia & 5 & 8,1 \\
17-25 (Remaja Akhir) & 52 & 83,9 \\
26-35 (Dewasa Awal) & 5 & 8,1 \\
36-45 (Dewasa Akhir) & & \\
\hline Jenis Kelamin & 13 & 21,0 \\
Laki - laki & 49 & 79,0 \\
Perempuan & & \\
\hline Pendidikan & 4 & 6.5 \\
SD & 13 & 29,0 \\
SMP & 38 & 61,3 \\
SMA & 2 & 3,2 \\
Perguruan Tinggi & & \\
Pekerjaan & 1 & 1,6 \\
PNS & 5 & 8,1 \\
Petani & 15 & 24,2 \\
Kary.Swasta & 5 & 8,1 \\
Wiraswasta & 36 & 58,1 \\
IRT & & \\
\hline Hubungan Dengan Pasien & 9 & 14,5 \\
Ayah & 53 & 85,5 \\
Ibu & &
\end{tabular}

Tabel 2.

Lama Rawat inap, Tingkat Pengetahuan, Peilaku Caring, dan Tingkat Kecemasan Perawat $(n=62)$

\begin{tabular}{lcc}
\hline \multicolumn{1}{c}{ Kategori } & $\mathrm{f}$ & $\%$ \\
\hline Rawat Inap & & \\
Lama(>3 hari) & 42 & 67,7 \\
Cepat (1-3 hari) & 20 & 32,3 \\
\hline Tingkat Pengetahuan & & \\
Kurang & 28 & 45,2 \\
Cukup & 17 & 27,4 \\
Baik & 17 & 27,4 \\
\hline Perilaku Caring Perawat & & \\
Kurang & 34 & 54,8 \\
Baik & 28 & 45,2 \\
\hline Tingkat Kecemasan & & \\
Tidak ada gejala & 3 & 4,6 \\
Ringan & 6 & 9,2 \\
Sedang & 18 & 27,7 \\
Berat & 32 & 49,2 \\
Sangat berat & 3 & 4,6 \\
\hline
\end{tabular}


Tabel 3.

Tabulasi Silang Rawat Inap dengan Tingkat Kecemasan Orangtua pada Anak Usia Prasekolah yang di Hospitalisasi $(n=62)$

\section{Tingkat Kecemasan}

\begin{tabular}{lccccccccccccc}
\cline { 2 - 11 } Rawat Inap & $\begin{array}{c}\text { Tidak } \\
\text { Ada } \\
\text { Gejala }\end{array}$ & $\begin{array}{c}\text { Sangat } \\
\text { Berat }\end{array}$ & Berat & Sedang & Ringan & Jumlah & $\begin{array}{c}p \text { - } \\
\text { value }\end{array}$ \\
& f & $\%$ & f & $\%$ & f & $\%$ & f & $\%$ & f & $\%$ & f & $\%$ & \\
\hline Lama (>3 hari) & 1 & 1,6 & 1 & 1,6 & 27 & 43,5 & 16 & 33,3 & 3 & 4,8 & 48 & 77,4 & \multirow{2}{*}{0,022} \\
Cepat (1-3 hari) & 2 & 3,2 & 2 & 3,2 & 5 & 8,1 & 2 & 3,2 & 3 & 4,8 & 14 & 22,6 & \\
\hline
\end{tabular}

Tabel 3 Tabulasi Silang Rawat Inap Dengan Tingkat Kecemasan Orang Tua Pada Anak Usia Prasekolah Yang di Hospitalisasi Di RSU Mitra Medika Medan, dapat diketahui jumlah 62 responden $(100 \%)$ yang mengalami rawat inap lama (>3hari) dengan tingkat kecemasan berat dengan jumlah 27 responden $(43,5 \%)$ dan rawat inap cepat (1-3 hari) dengan tingkat kecemasan berat dengan jumlah 5 responden presentase $(8,1 \%)$. Setelah dilakukan analisa bivariat dengan menggunakan uji statistik chi-square di peroleh nilai $p$-value $=0,022(\mathrm{p}<0,05)$, Ho ditolak dan Ha diterima artinya ada hubungan frekuensi lama rawat inap dengan tingkat kecemasan orang tua terhadap hospitalisasi anak usia prasekolah di Rumah Sakit Mitra Medika Medan.

Tabel 4.

Tabulasi Silang Tingkat Pengetahuan Orangtua dengan Tingkat Kecemasan Orangtua pada Anak Usia Prasekolah $(\mathrm{n}=62)$

\section{Tingkat Kecemasan}

Tingkat Tidak Ada Sangat

Pengetahuan

Berat Sedang Ringan Jumlah

p-value

\begin{tabular}{lccccccccccccc} 
& $\mathrm{f}$ & $\%$ & $\mathrm{f}$ & $\%$ & $\mathrm{f}$ & $\%$ & $\mathrm{f}$ & $\%$ & $\mathrm{~F}$ & $\%$ & $\mathrm{f}$ & $\%$ & \\
\cline { 2 - 9 } Kurang & 2 & 3,2 & 3 & 4,8 & 32 & 51,6 & 12 & 19,4 & 6 & 9,7 & 55 & 88,7 & \\
Cukup & 0 & 0 & 0 & 0 & 0 & 0 & 1 & 1,6 & 0 & 0 & 1 & 1,6 & 0,043 \\
Baik & 1 & 1,6 & 0 & 0 & 0 & 0 & 5 & 8,1 & 0 & 0 & 6 & 9,7 & \\
\hline
\end{tabular}

Tabel 5.

Tabulasi Silang Perilaku Caring dengan Tingkat Kecemasan Orangtua pada Anak Usia Prasekolah yang di Hospitalisasi $(n=62)$

\begin{tabular}{|c|c|c|c|c|c|c|c|c|c|c|c|c|c|}
\hline \multirow{3}{*}{$\begin{array}{c}\text { Perilaku } \\
\text { Caring } \\
\text { Perawat }\end{array}$} & \multicolumn{10}{|c|}{ Tingkat Kecemasan } & \multirow{2}{*}{\multicolumn{2}{|c|}{ Jumlah }} & \multirow{3}{*}{$\begin{array}{c}p- \\
\text { value }\end{array}$} \\
\hline & \multicolumn{2}{|c|}{$\begin{array}{l}\text { Tidak } \\
\text { Ada } \\
\text { Gejala } \\
\end{array}$} & \multicolumn{2}{|c|}{$\begin{array}{c}\text { Sangat } \\
\text { Berat }\end{array}$} & \multicolumn{2}{|c|}{ Berat } & \multicolumn{2}{|c|}{ Sedang } & \multicolumn{2}{|c|}{ Ringan } & & & \\
\hline & $\mathrm{f}$ & $\%$ & $\mathrm{f}$ & $\%$ & $\mathrm{f}$ & $\%$ & $\mathrm{f}$ & $\%$ & $\mathrm{f}$ & $\%$ & $\mathrm{f}$ & $\%$ & \\
\hline Kurang & 1 & 1,6 & 0 & 0 & 24 & 38,7 & 13 & 21,0 & 2 & 3,2 & 40 & 64,5 & $0,0>4$ \\
\hline Baik & 2 & 3,2 & 3 & 4,8 & 8 & 12,9 & 5 & 8,1 & 4 & 6,5 & 22 & 35,5 & 0,024 \\
\hline
\end{tabular}

Tabel 4 diketahui bahwa tingkat pengetahuan dimasukkan dalam kategori kurang dengan tingkat kecemasan dimasukkan dalam kategori berat sebanyak 32 responden $(51,6 \%)$, yang mengalami tingkat pengetahuan 
kategori baik dengan tingkat kecemasan kategori sedang berjumlah 5 responden $(8,1 \%)$. Setelah dilakukan analisa bivariat dengan menggunakan uji statistik chi-square di peroleh nilai $p$ value $=0,043(\mathrm{p}<0,05)$, Ho ditolak dan Ha diterima artinya ada hubungan frekuensi tingkat pengetahuan orang tua dengan tingkat kecemasan orang tua terhadap hospitalisasi anak usia prasekolahdi Rumah Sakit Mitra Medika Medan.

Tabel 5 Tabulasi Silang Perilaku Caring Dengan Tingkat Kecemasan Orangtua Pada Anak Usia Prasekolah yang di Hospitalisasi di Rumah Sakit Mitra Medika Medan. Data yang didapatkan bahwa perilaku Caring perawat kategori kurang dengan tingkat kecemasan kategori berat sebanyak 24 responden $(38,7 \%)$ dan yang mendapat perilaku Caring perawat baik dengan tingkat kecemasan ringan dengan jumlah 4 berpresentase $(6,5 \%)$. Setelah dilakukan analisa bivariat dengan menggunakan uji statistik chi-square di peroleh nilai $p$-value $=0,024(\mathrm{p}<0,05)$, Ho ditolak dan Ha diterima artinya ada hubungan frekuensi $\mathrm{p}$ erilaku carring perawat dengan tingkat kecemasan orang tua terhadap hospitalisasi anak usia prasekolahdi Rumah Sakit Mitra Medika Medan.

\section{PEMBAHASAN}

\section{Faktor Rawat Inap Dengan Tingkat Kecemasan Orang Tua Pada Hospitalisasi Anak Prasekolah}

Lama hari rawat diartikan sebagai salah satu indikator mutu pelayanan medis yang diberikan oleh rumah sakit kepada pasien rawat ,rawat inap menunjukkan berapa hari rawatan pasien dirawat inap pada satu periode perawatan (Ade, 2017).
Menurut penelitian yang dilakukan Mc Cherty, Kozak dalam Hikmawati (2003) mengatakan bahwa hamper 4 juta anak prasekolah dalam satu tahun mengalami hospitalisasi. Rata-rata jumlah rawatan kurang lebih selama 6 hari. Waktu lama rawatan anak lebih banyak pada waktu merawat orang dewasa sekitar $20-45 \%$. Hal ini sejalan dengan penelitian yang dilakukan oleh Kurniawati (2011) yang mengatakan bahwa data di Indonesia teradapat lebih kurang dari 5.000.000 anakan yang menjalani rawat inap di rumah sakit. Masalah anak dengan hospitalisasi cenderung akan menimbulkan kecemasan terhadap orang tua yang mengalami hospitaliasi anak di rumah sakit.

Faktor Tingkat Pengetahuan Dengan Tingkat Kecemasan Orang Tua Pada Hospitalisasi Anak Prasekolah

Pengetahuan ialah hal yang utama dalam membentuk perilaku tindakan seseorang. Pengalaman dan penelitian memperlihatkan bahwasanya perilaku yang mempunyai pengetahuan yang baik akan memberikan nilai yang positif. (Wawan \& Dewi, 2015). Hal ini sejalan dengan penelitian yang dilakukan Indrayani dan Santoso (2012) yang mengemukakan bahwa pentingnya tenaga kesehatan memberikan pemahaman pada orang tua selama anak di rawat di rumah sakit. Salah satu metode yang tepat adalah dengan memberikan pendidikan kesehatan terkait dengan pengetahuan orangtua terhadap penyakit yang dialami anak sehingga mengurangi kecemasan oarng tua dan keluarga.

Faktor Perilaku Caring Dengan Tingkat Kecemasan Orang Tua Pada Hospitalisasi Anak Prasekolah

Perilaku Caring perawat merupakan bagian paling penting yang dianggap sebagai kunci dasar dalam penyedian 
fasilitas pelayanan kesehatan kepada pasien dan juga suatu proses interpersonal yang mencakup pemberian layanan kesehatan, membangun hubungan saling percaya yang dekat antara pasien dan penyedia layanan. Perilaku Caring perawat diantaranya menghormati pasien, memberikan rasa aman dan memenimalkan kecemasan pasien, komunikasi yang baik dan positif (Modic et al, 2014).

Penelitian yang dilakukan Kartikasari (2017) mengatakan bahwa perilaku caring yang diterapkan perawat dapat memberikan nilai positif kepada orang tua dan keluarga selama masa rawatan anak serta mampu mengurangi kecemasaan dengan memberikan informasi yang lengkap dan tepat waktu. Hal ini sejalan dengan penelitian yang dilakukan Siswanti dan Sukesi (2017) yang mengatakan bahwa komunikasi perawat dalam memberikan informasi kepada orang tua dan keluarga pasien selama hospitalisasi anak akan memberikan dampak positif dan mengurangi rasa kecemasan.

\section{Hubungan Tingkat Pengetahuan Orang Tua Dengan Tingkat Kecemasan Orang Tua Di RSU Mitra Medika}

Penelitian yang dilakukan Marlina (2015) menyatakan bahwa faktor pengetahuan berpengaruh terhadap kecemasan orang tua terkait hospitalisasi anak. Sebanyak tingkat pengetahuan seseorang yang rendah akan cenderung lebih mudah mengalami kecemasan dibanding seseorang yang mempunyai tingkat pengetahuan yang tinggi. Oleh karena itu pengetahuan yang didapat dari pengajaran format dan informal akan memberikan nilai yang positif bagi lingkungannya dan semakin banyak pengetahuan yang didapatkan akan memberikan efek yang baik pulak di lingkungan sekitar. Begitu pun sebaliknya. Hal ini yang menjadi dasar bahwa pengetahuan tidak hanya diperooleh dari hal yang formal saja dari lingkungan luar pun dapat dijadikan pengetahuan.

Dapat dikaitkan dari hasil penelitian yang didapat bahwa orang tua yang tingkat pengetahuanya kurang dengan hospitalisasi anak prasekolah di rumah sakit akan mengalami peningkatan kecemasan kategori berat, sedangkan orang tua yang tingkat pengetahuanya baik dengan hospitalisasi anak prasekolah di rumah sakit akan mengalami tingkat kecemasan yang ringan.

\section{Hubungan Perilaku Caring Perawat dengan tingkat kecemasan orang tua terhadap hospitalisasi anak usia prsekolah di Rumah Sakit Mitra Medika}

Penelitian yang dilakukan Pardede dan Simamora (2020) mengatakan bahwa perilaku caring perawat menciptakan wujud kinerja baik bagi perawat. Caring perawat yang baik akan berkaitan dengan tingkat kecemasan orang tua yang anaknya hospitalisasi, karena dengan perilaku Caring perawat akan meningkatkan mutu pelayanan kesehatn dan kualitas rumah sakit. Hal ini sejalan dengan penelitian yang dilakukan Wahyuni (2020) mengatakan penerapan perilaku caring yang dapat di wujudkan dengan bentuk dukungan emosional, memberikan perhatian, pemberian informasi akan meningkatkan pelayanan yang lebih baik.

Dapat dikaitkan dari hasil penelitian yang didapat bahwa perilaku Caring perawat yang kurang seperti memberikan informasi, pemberian 
pendidikan kesehatan terkait penyakit akan menyebabkan tingkat kecemasan orang tua meningkat. Karena pada saat anak dihospitalisasi orang tua cenderung mengalami kecemasan oleh karena itu perlunya perilaku perawat untuk dapat meredahkan kecemasan orang tua.

\section{SIMPULAN}

Data yang didapat dari hasil analisa univariat berdasarkan faktor rawat inap (>3hari) masuk dalam kategori lama sebanyak 42 responden $(67,7, \%)$, faktor tingkat pengetahuan responden masuk dalam kategori kurang sebanyak 28 responden $(45,2 \%)$, dan faktor perilaku Caring perawat masuk dalam kategori kurang sebanyak 34 responden $(54,8 \%)$, faktor tingkat kecemasan masuk dalam kategori berat sebanyak 32 responden $(49,2 \%)$.

Data yang didapat dari hasil analisa bivariat terdapat hubungan rawat inap dengan tingkat kecemasan orang tua terhadap hospitalisasi anak usia prasekolah $p$ value $=0,022$, terdapat hubungan frekuensi tingkat pengetahuan dengan tingkat kecemasan orang tua terhadap hospitalisasi anak usia prasekolah dengan hasil $p$ value $=$ 0,043 dan terdapat hubungan perilaku carring perawat dengan tingkat kecemasan orang tua terhadap hospitalisasi anak usia prasekolah dengan hasil $p$ value $=0,024$.

\section{DAFTAR PUSTAKA}

Anggika, A., \& Wahyuni. (2016). 'Tingkat Kecemasan Pada Anak Prasekolah Yang Mengalami Hospitalisasi Berhubungan Dengan Perubahan Pola Tidur Di RSUD Karanganyar. Jurnal Stikes Aisyiyah http://www.jurnal.stikesaisyiyah.ac.id/index.php/gaster/art icle/view/121.
Ade HSDSKN. (2017). Buku Ajar Asuhan Keperawatan jiwa. Yogyakarta: Nuha Medika;. 41 p.

Alini, A. (2017). Pengaruh terapi bermain plastisin (playdought) terhadap tingkat kecemasan anak usia prasekolah (3-6 tahun) yang mengalami hospitalisasi di ruang perawatan anak RSUD Bangkinang tahun 2017. Jurnal Ners Tuanku Tambusai. http://repository.poltekkestjk.ac.id/503/6/DAPUS.pdf.

Hulinggi I, Masi G, Ismanto A.Y, Studi P, Keperawatan I, Kedokteran F, et al. (2018). Hubungan Sikap Perawat Dengan Stres Akibat Hospitalisasi Pada Anak Usia Pra Sekolah Di Rsu Pancaran Kasih Gmim Manado. Jurnal Keperawatan (e-Kp). https://ejournal.unsrat.ac.id/index. php/jkp/article/view/19479/19030.

Hikmawati. (2003). Pendidikan dalam keperawatan . Jakarta : Salemba Medika

Pardede, J.A A \& Simamora, M. (2020). Caring Perawat Berhubungan Dengan Kecemasan Orang Tua Yang Anaknya Hospitalisasi. Jurnal Penelitian Perawat Profesional, 2(2), 171178.

https://doi.org/10.37287/jppp.v2i2 .93

Indrayani, A., \& Santoso, A. (2012). Hubungan Pendidikan Kesehatan dengan Kecemasan Orangtua pada Anak Hospitalisasi. Jurnal Nursing Studies, 1(1), 163-168.

Modic. M.B., Siedlecki, S.L.,Quinn, M.T., Griffin. (2014). Caring Behavior: Parception of acute Care Nurses and Hospitalized 
Patients With Diabetes. Jurnal of Patient Experience. https://doi.org/10.1177/23743743 1400100107.

Marlina, L. (2015). Pengetahuan Dengan Reaksi Dan Kecemasan Orangtua Akibat Hospitalisasi Anak Knowledge Between Parents' Reactions and Anxieties Due To Children'S Hospitalization. J JIM FKEP. ;IV(1):25-33.

Sarfika, R., Yanti, N., \& Winda, R. (2015). Pengaruh Teknik Distraksi Menonton Animasi Kartun Animasi Terhadap Skala Nyeri Anak Usia Pra Sekolah Saat Pemasangan Infus Di Instalasi Rawat Inap Anak RSUP DR. M. Djamil Padang. Ners Jurnal Keperawatan, 11 (1), 32-40.

Siswanti, H \& Sukesih. (2017). Hubungan Komunikasi Teraupetik Dengan Kecemasan Akibat Hospitalisasi Pada Aanak Usia Pra Sekolah Yang di Rawat Di RSU Sultan Hadirin Kabupaten Jepara Tahun 2017. Jurnal Ilmu Keperawatan dan Kebidanan Vol.8 No.2. https://ejr.stikesmuhkudus.ac.id/in dex.php/jikk/article/view/352/245.

Kaluas, I., Ismanto, A.Y., \& Kundre R.M. (2015). Perbedaan Terapi Bermain Puzzle Dan Bercerita Terhadap Kecemasan Anak Usia Prasekolah (3-5 Tahun) Selama Hospitalisasi Di Ruang Anak RS TK. III. R. W. Mongisidi Manado. Jurnal Keperawatan (e-Kp). https://ejournal.unsrat.ac.id/index. php/jkp/article/view/7969.

Kemenkes RI. (2018). Profil Kesehatan Indonesia. Jakarta : Kementerian Kesehatan RI.
Kurniawati, Id. (2011). Hubungan Peran Keluarga Terhadap Hospitalisasi Pada Anak Toddler di Ruang Melati Rumah sakit Mekar Sari Bekasi: Program Study S1 Ilmu Keperawatan STIkes MI. Skripsi.

Wahyuni, D. (2020). Hubungan Peilaku Caring Perawat dengan Tingkat Kecemasan Orang Tua Terkait Prosedur Invasif Pada Pasien Anak Di RSUD dr. Haryoto Lumajang. Program Study S1 Keperawatan Universitas Jember. Skripsi.

http://repository.unej.ac.id/handle/ $\underline{123456789 / 99131}$

Windiarto \& Yanto. (2018). Buku Ilmu Pendidik. ;5(1):12-21.

Wulandari, M \& Ernawati, M. (2016). Buku Ajar Keperawatan Anak. Yogyakarta: Pustaka Pelajar.

WHO. World Health Statistics (2015). World Health Organization. 
Jurnal Penelitian Perawat Profesional, Volume 3 No 3 Hal 565 - 574, Agustus 2021 Global Health Science Group 